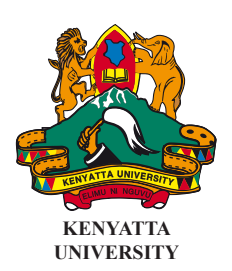

ISSN 1563-1028

\section{CHEMCHEMI}

International Journal of Humanities and Social Sciences

\title{
EFFICACIES OF 2-D ANIMATION IN HEALTH AND SECURITY COMMUNICATION
}

\author{
George Vikiru
}

\begin{abstract}
Health is categorized as a security issue as its lack causes individuals to fall ill, be disabled or die. Being deficient of health can therefore disrupt entire populations, economies, and governments. The Copenhagen School proposed the Securitization Theory that could be applied in the identification and response to given health threats. Part of the theory's strategy is the use of effective communication in mobilizing groups that would combat identified health threats. Other studies have reported the use of 2-D Animation, a type of ICT-based solution, as gaining currency in situations where it is important to get the message through to communities and have it correctly internalized. This paper puts a case for the utilization of 2-D Animation for effective communication in society for health and security. It reports a study that sought to establish whether 2-D Animation was effective in communicating good hygiene practice messages to children in Githurai Location, Kiambu County, Kenya. The study first identified how good hygiene practice messages were being communicated in the area. An experimental target group was then treated with a 2-D animation developed for study before psychometrics were applied to determine its efficacy in effectively communicating the messages. Data obtained was analyzed using independent t-tests and a one-way Analysis of Variance (ANOVA) of the Statistical Package for Social Sciences (SPSS). The findings showed a significant difference between the experimental group and the control group that had not been treated with the animation $(\mathrm{t}(292)=5.031, \mathrm{p} \otimes 0.001)$. The findings further indicated a significant difference in all the thinking skills of the Bloom's Taxonomy of Educational Objectives of the Cognitive Domain except evaluation. The results therefore put a case for 2-D Animation's consideration as an ICT mitigator for effective communication in society for health and security.
\end{abstract}

Key words: Effective Communication; Health Threat; 2-D Animation; Mitigator

\section{Introduction}

The 1994 United Nations Development Programme's (UNDP) annual report titled New Dimensions of Human Security identified health as one of the seven fields critical to human security. Health, that encompasses infectious diseases in the developing world as well as lifestyle diseases in the developed world, was classified because of its effect to society. Smolinski, Hamburg and Lederman (2003, p. 42) writes that, 'disease- causing microbial agents that occur naturally or are intentionally inflicted, can cause illness, disability, and death in individuals while disrupting entire populations, economies, and governments.'

In cognizance of the effect of health on human security, the Copenhagen School proposed the Securitization Theory that could be applied when identifying and mapping out responses to health threats. The theory details avenues that should be followed when identifying health threats, mobilizing target audiences to combat the threats providing emergency resources for all involved and once liquidated, the processes that should be followed when de-securitizing the health threats. Typical agencies that would be mobilized 
to combat health threats include: the World Health Organization (WHO); government departments; business groups; civil society organizations; health officials; the general public and the media. Yuk-ping and Thomas (2010) write that marshalling together these agencies is the most critical of the Securitization Theory, as omission of any one cohort (or failure of any) would jeopardize the effective securitization of the health threat. Lancet (2009) asserts that for a health threat to be governed 'transparency and effective communication between the WHO, governments, health officials, the public, and the media is paramount.

Effective communication between groups has been a recommendation of many scholarly studies that have focused on social development in communities. The 2002 World Summit on Sustainable Development (WSSD) Conference held in Johannesburg, South Africa for instance, gave commitments on the use of Information Communication Technology (ICT) - based solutions as interventions for effective communication. Effective communication is said to lead to a significant increase in 'retention of information for longer periods' (Baker, Barret and Roberts, 2002), and eventually to a significant increase in acquisition of knowledge. Increased acquisition of knowledge, for example of good hygiene practice, would impact positively on community health and societal development (WHO and Water Supply and Collaboration Council, 2005). 2-D Animation has specifically been identified as that type of ICT-based technology that can be utilized to achieve the WSSD objective (Gichuki, Vikiru and Nyaga, 2007; WHO and Water Supply and Sanitation Collaborative Council, 2005; GoK, 1976). 2-D animation has over the years, been reported to 'gain a new and wider use, especially in situations where it is important to get the message through and have it internalized' (Ginman and von Ungern-Sternberg, 2003, p. 69). This paper puts a case for the utilization of 2-D Animation for effective communication with agencies that are being mobilized to combat identified health threats for Health and Security. It reports a study that sought to improve the hygiene practice of children living in Githurai Location, Kiambu County - a periurban region $25 \mathrm{~km}$ north of Nairobi, Kenya. The study intended to establish how good hygiene practice messages on preventative health care could effectively be communicated to the children. That study is discussed hereafter.

\section{Effective Health Communication}

Communication is defined differently by different authors because they all tend to take different perspectives of the subject. Effective communication, however, is determined by the content of a message and the way the message is presented. Brown (2011) writes that effective communication takes place when a transmitted message is received and correctly interpreted by its audience. Norton (1983) indicates that effective communication takes place if the communication styles are based on the personality trait of the source and the receiver. Baker, Barrett and Roberts (2002) write about other indicators for effective communication that include: what is intended to be communicated, the method of achieving that communication, the development of shared understanding between source and receiver and the learning styles that interpret other people's messages and communicate one's own. Kelly (2010) outlined steps to consider for effective communication. These include: the selection of the right medium; connecting with feedback; listening closely; summarizing in one's own words and paying attention to non-verbal communication.

This paper puts a case for the utilization of 2-D Animation, a type of ICT-based solution, for effective communication in society for health and security. It ensured effective communication through the following:

a) Incorporating the personality of the children, their expressions, expectations and emotional states in the animation produced for the study.

b) Relating the animation produced to the audience's age, region, sex and intellectual ability.

c) Professionally and skillfully producing the visuals and voice over's for the animation used in the study. 


\section{Animation as a Computer Based Instruction}

Computers are used to produce animations and also as a medium of instruction. Computer-Based Instructions (CBIs) utilize computers that give the viewer opportunities that cannot be offered in the physical world. CBIs offer their recipients unique intellectual experiences and opportunities. Computer-Based Instructions (CBIs) are classified into two: Animated Visual Displays (AVDs) and Static Visual Displays (SVDs). 2-D Animation is an example of an AVD since it utilizes the principle of motion during presentations. AVDs are devices that are used for attracting attention, maintaining motivation and representing domain knowledge involving explicit and implicit movement, for example, simulation. Woolf et al., (1986) view AVDs as aids for explaining complex knowledge or phenomena. He goes on to suggest five instructional conditions in which this happens: (i) demonstrating procedural actions; (ii) simulating system behaviors; (iii) explicitly representing the invisible; (iv) illustrating structural, functional and procedural relationships among objects/events and (iv) focusing the learners' attention to important concepts. This paper took into consideration the theoretical and pedagogical rationales of the subject matter while developing its 2-D animation. For example, it demonstrated procedural actions in good hygiene by animating the processes of hand-washing after a visit to the washroom and gave details of the correct procedure for using a toilet. By use of additional text and other effects, the 2-D animation also focused the learners to put these good actions into memory and practice.

\section{Health and Security}

In 1994, the United Nations Development Programme released its annual report entitled, 'New Dimensions of Human Security', that identified health security as encompassing infectious diseases in the developing world as well as lifestyle diseases in the developed world. A notable gap in the report was the understanding of how health challenges come to be identified as security threats. This gap had been explained by the Copenhagen School (Buzan, Wæver and de Wilde, 1998).

The Copenhagen School posited that the course of threat identification and response could be broken down into several phases (Buzan et al., 1998). The first phase is the identification of the threat. This is followed by the acceptance of the issue by a target audience (usually civil society). With this acceptance comes a third phase whereby an emergency (extra-budgetary) reallocation of resources is made to combat the threat. Once the threat is successfully resolved, the issue is de-securitized to an extent that, if still present, it simply becomes part of the general policy environment.

Focusing on the second phase of threat identification and response, this paper put up a case for the use of effective communication in mobilizing groups that would combat identified health threats. It puts a case for the consideration of 2-D Animation, a type of ICT-based solution, for effective communication in society for health and security.

\section{Methodology}

Children were the focus of the study as 'being visual learners they get attracted to animations easily,' (Baker et al., 2002 p. 23). Further, for an in-depth study, only children in Standard Two (2) of age group between 7 and 9 years were targeted. The choice of Standard 2 was informed by the expectation of the Kenya Institute of Education (KIE) syllabus (2002) that good hygiene practice be taught to the children in class. A total of 320 pupils, drawn from private and public schools and equally from either gender, were involved in the study.

To determine the efficacy of 2-D animation in effective communication between source and receiver, psychometrics were applied through criterion- referenced tests. The tests were attempted by pupils, half of whom had been 'treated' with a 2-D animation that had been specifically developed for the study (the experimental group). The other children were in the control group that wasn't shown the animation. A null research hypothesis, 'that there would be no significant difference by respondents' acquisition of knowledge on good hygiene practice after exposure to 2-D animation,' was proposed and a quasi- 
experimental research design used to test the hypothesis.

A 2-D animation was specifically developed for the study. The animation was developed by a purposively selected professional animator. The animator was guided by a detailed brief developed by the researcher. The brief was based on the three themes of the Standard 2 KIE syllabus: caring for personal hygiene; cleaning the physical environment and proper use of latrines/washrooms. The animator collated supplementary information from the study area to use in the animation's production. Such information included: the personality of the target population; the social context of the study area; the desired duration of the animations; the language to use and the kind of voice-overs and sound jingles to be applied. The animator eventually capitalized on the technological capacity that 2-D animation affords to produce a flawless animation that communicated the intended messages on good hygiene practice to the target group. The Aestheic Value (AV) of the animation was verified by four (4) purposively selected art critics and animation professionals. The communication in the animation formed Artist's Intention (AI) of the study.

Criterion-referenced tests were used to quantify the reception of the communication from the animator by the pupils. The tests were based on five of the six skills spelt out in the Bloom's Taxonomy of Educational Objectives of the Cognitive Domain, namely Knowledge, Comprehension Application, Analysis, Synthesis and Evaluation.

First, the pupils in the experimental and control groups were pre-tested. This was done during the second term of the calendar year after both groups had been through classroom teaching of the subject of hygiene in their first term. Prior teaching and learning of the subject ensured that all the pupils in the two groups had the same skills before the intervention was introduced. The experimental group was thereafter exposed to the developed animation. After a period of two weeks (Mugenda, 2008, p. 78; McAlpine, 2002 , p. 12), both the experimental and control groups were again post-tested with the tests. This was to establish any changes in the responses to the instrument after the respondents of the experimental group had been exposed to the animation.

Analysis of the test results, based on each of the five selected ranges of thinking skills in the Bloom's Taxonomy, was done using the Statistical Package for Social Sciences (SPSS). An independent t-test at a set significance level of ( $\mathrm{p} \otimes 0.05$ ) was used to measure the $\mathrm{p}$-values, mean scores and standard deviations obtained by pupils.

\section{Results}

The study first sought to establish if there were sanitation concerns in the area that could affect the hygiene of children. Figure 1 indicates the responses obtained.

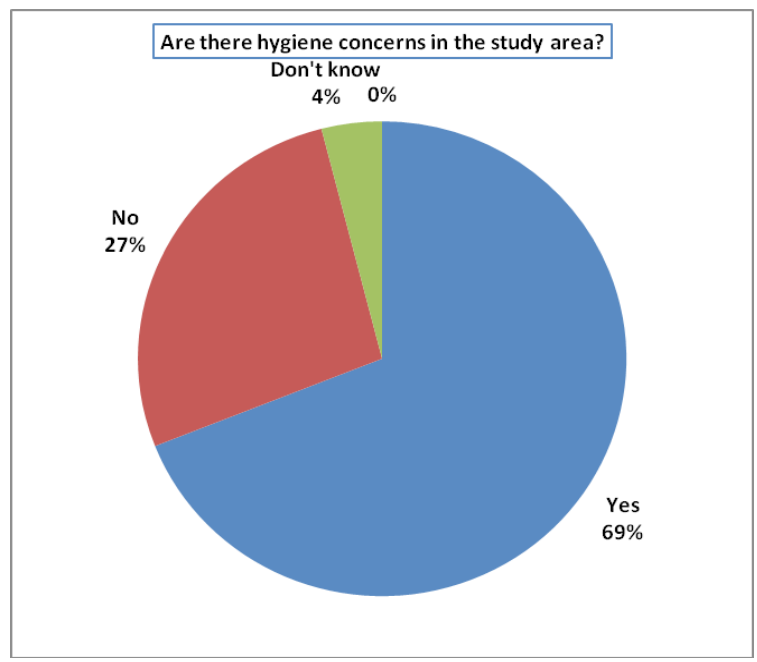


Out of a total tally of $42(\mathrm{~N}=42)$ a majority $(69 \%)$ of the respondents reported that the area under study had sanitation issues that could affect the hygiene of children living in the area. The specific hygiene concerns cited are indicated in Table 1.

Table 1: Type of hygiene concerns in the study area

\begin{tabular}{ccccccc} 
Percentage & $\begin{array}{c}\text { Lack of } \\
\text { Water/Unclean } \\
\text { Water }\end{array}$ & $\begin{array}{c}\text { Lack of } \\
\text { Clean } \\
\text { Toilets }\end{array}$ & $\begin{array}{c}\text { Lack of } \\
\text { Garbage } \\
\text { Disposal } \\
\text { Mechanisms }\end{array}$ & $\begin{array}{c}\text { Spilling } \\
\text { Sewers }\end{array}$ & $\begin{array}{c}\text { Poor } \\
\text { Drainage }\end{array}$ & $\begin{array}{c}\text { Lack of } \\
\text { Body } \\
\text { Hygiene }\end{array}$ \\
\hline$\%$ & 25.6 & 25.6 & 18 & 15.3 & 12.8 & 2.7
\end{tabular}

A survey of the primary school curriculum was done to ascertain if there was any good hygiene practice messages communicated to the affected children. The Standard Two Science Syllabus (KIE, 2002) requires that the following areas of hygiene be taught: care for personal hygiene; cleaning of the physical environment and proper use of latrines and toilets. The Science School teacher respondents affirmed that all three areas were taught. A majority (91\%) indicated that the content covered had sufficient as good hygiene practice messages for the affected children (Figure 2).

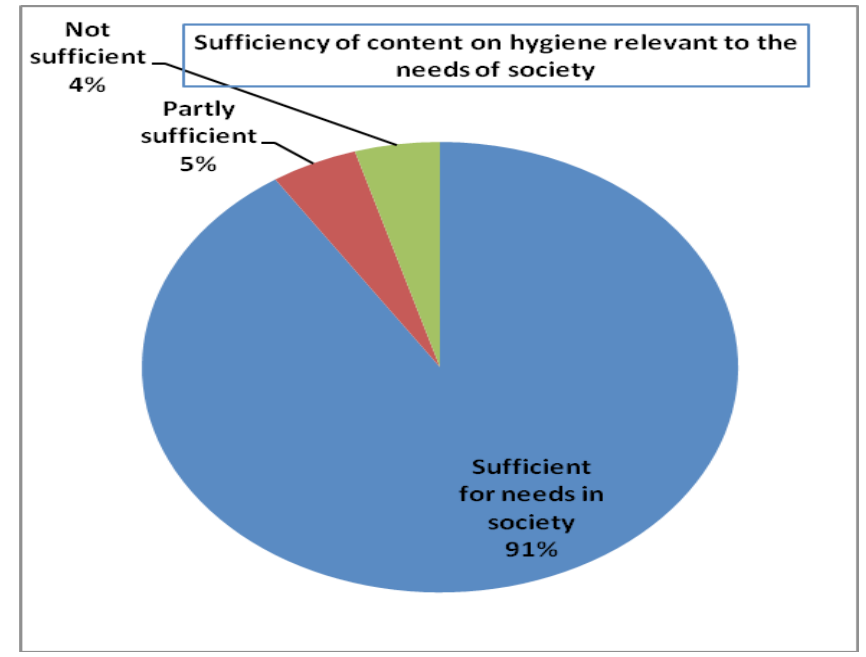

Figure 2: Responses on sufficiency of content of hygiene topics relevant to the needs of the study area

It was further established that 2-D animation was not one of the methodologies used in teaching of hygiene and related topics in the schools. The respondents only mentioned the methodologies in Table 2 as used to communicate good hygiene practice messages.

Table 2: Methods used to communicate good hygiene practice messages

in the study area 


\begin{tabular}{lcccc}
\hline Percentage & $\begin{array}{l}\text { Practically } \\
\text { using plays } \\
\text { and song }\end{array}$ & $\begin{array}{c}\text { Face } \\
\text { to face } \\
\text { discussion }\end{array}$ & $\begin{array}{c}\text { Using } \\
\text { Visual } \\
\text { Signage }\end{array}$ & $\begin{array}{c}\text { None } \\
\text { at all }\end{array}$ \\
\hline$\%$ & 65.2 & 19.6 & 4.3 & 10.9
\end{tabular}

Slightly over $50 \%$ of the respondents did not know why 2-D animation was not on of the methods used in communicating good hygiene practice messages to the affected children in the study area. The other reasons given on its non-use is as indicated in Table 3:

Table 3: Why 2-D Animation isn't one of the instructional resources used in communicate good hygiene practice messages in the Study Area

\begin{tabular}{|c|c|c|c|c|c|}
\hline $\begin{array}{l}\text { No of } \\
\text { Respondents }\end{array}$ & $\begin{array}{l}\text { Respondents } \\
\text { are too } \\
\text { young }\end{array}$ & $\begin{array}{c}\text { No } \\
\text { Facilities } \\
\text { and resources }\end{array}$ & $\begin{array}{r}\text { Not in } \\
\text { Syllabus }\end{array}$ & $\begin{array}{c}\text { Time } \\
\text { Shortage }\end{array}$ & $\begin{array}{l}\text { Don't } \\
\text { Know }\end{array}$ \\
\hline $\begin{array}{l}\text { From } \\
\text { Teachers } \\
\text { Questionnaire }\end{array}$ & 3 & 7 & 1 & 1 & 19 \\
\hline $\begin{array}{l}\text { From } \\
\text { Teachers } \\
\text { Interviews }\end{array}$ & 1 & 6 & 0 & 0 & 1 \\
\hline Tally $=39$ & 4 & 13 & 1 & 1 & 20 \\
\hline Percentage & 10.2 & 33.3 & 2.6 & 2.6 & 51.3 \\
\hline
\end{tabular}

The second objective of the study was to determine the efficacy of 2-D animation in effective communication between source and receiver. Pre-test results of pupils in the control and experimental schools were compared to determine the congruency of the experimental and control groups before treatment (Fraenkel et al., 2009). The analysis of mean scores of the two groups indicated that the differences were negligible (Table 4).

Table 4: Comparison of Mean Scores of Pre-test Control and Pre-test Groups

\section{Experimental}

\begin{tabular}{lcccccc}
\hline Mean Scores & Knowledge & $\begin{array}{c}\text { Compre- } \\
\text { hension }\end{array}$ & $\begin{array}{c}\text { Applica- } \\
\text { tion }\end{array}$ & Analysis & Synthesis & $\begin{array}{c}\text { Evalua- } \\
\text { tion }\end{array}$ \\
\hline Control & 21.8 & 5.7 & 6.27 & 4.72 & 5.07 & 0.95 \\
Experimental & 20.67 & 5.65 & 6.21 & 4.52 & 4.88 & 0.94 \\
\hline
\end{tabular}

To verify whether the differences in the mean scores mentioned in Table 4 were significant, a t-test of the scores was done and the p-values and Standard Deviations (SD) calculated. The results are shown in Table 5. 


\begin{tabular}{|c|c|c|c|c|c|c|c|}
\hline Mean Scores & $\begin{array}{l}\text { Know- } \\
\text { ledge }\end{array}$ & $\begin{array}{l}\text { Compre- } \\
\text { hension }\end{array}$ & $\begin{array}{l}\text { Applica- } \\
\text { tion }\end{array}$ & Analysis & Synthesis & $\begin{array}{l}\text { Evalua- } \\
\text { tion }\end{array}$ & $\begin{array}{l}\text { Percentage } \\
\text { Total }\end{array}$ \\
\hline \multicolumn{8}{|l|}{ Experimental } \\
\hline $\mathrm{N}=140$ & 3.926 & 1.587 & 1.234 & 0.995 & 1.399 & 0.241 & 16.759 \\
\hline \multicolumn{8}{|l|}{ SD } \\
\hline \multicolumn{8}{|l|}{ Control } \\
\hline $\mathrm{N}=154$ & 3.462 & 1.464 & 1.023 & 0.670 & 1.153 & 0.214 & 13.505 \\
\hline \multicolumn{8}{|l|}{$\mathrm{SD}$} \\
\hline t-value & -1.182 & -0.306 & -0.412 & -1.993 & -1.319 & -0.513 & -1.180 \\
\hline $\mathrm{DF}(\mathrm{N}-2)$ & 292 & 292 & 292 & 292 & 292 & 292 & 292 \\
\hline $\mathrm{p}$-value & 0.238 & 0.760 & 0.681 & 0.047 & 0.188 & 0.609 & 0.239 \\
\hline
\end{tabular}

The p-values in Table 5.0 for all the thinking skills were greater than $0.05(\mathrm{p}, 0.05)$ meaning that the difference in the scores of the two groups was not significant. The two groups were therefore congruent prior to the experimental group being exposed to the animation.

To determine the effectiveness of 2-D animation due to the classification of the schools, a comparison of the post-test scores of the experimental schools and of the control schools was done. It revealed that the mean scores for the control groups were lower than the mean scores for the post-test experimental groups in all thinking skills apart from 'evaluation' (Table 6).

Table 6: Comparison of Mean scores of Post-test Control and Post-test Groups

\section{Experimental}

\begin{tabular}{lcccccc}
\hline Mean Scores & Knowledge & $\begin{array}{c}\text { Compre- } \\
\text { hension }\end{array}$ & $\begin{array}{c}\text { Applica- } \\
\text { tion }\end{array}$ & Analysis & Synthesis & $\begin{array}{c}\text { Evalua- } \\
\text { tion }\end{array}$ \\
\hline Control & 19.92 & 5.27 & 6.01 & 4.47 & 4.65 & 0.95 \\
Experimental & 22.03 & 6.12 & 6.49 & 4.79 & 5.34 & 0.94
\end{tabular}

Of all the thinking skills, 'knowledge' had the highest gain score indicated by $(22.03-19.92=2.11)$ (Table 6). The results suggest that, overall, the experimental group scored better than the control group. To determine how significant the differences in scores were, the t-values and Standard Deviations (SD) of the test scores were compared and the results indicated in Table 7.

Table 7: T-test Scores of Post-test Control and Post-test Experimental 


\begin{tabular}{lccccccc}
\hline Mean Scores & $\begin{array}{c}\text { Know- } \\
\text { ledge }\end{array}$ & $\begin{array}{c}\text { Compre- } \\
\text { hension }\end{array}$ & $\begin{array}{c}\text { Applica- } \\
\text { tion }\end{array}$ & Analysis & Synthesis & $\begin{array}{c}\text { Evalua- } \\
\text { tion }\end{array}$ & $\begin{array}{c}\text { Percentage } \\
\text { Total }\end{array}$ \\
\hline $\begin{array}{l}\text { Experimental } \\
\mathrm{N}=140\end{array}$ & 2.874 & 1.160 & 0.902 & 0.534 & 1.001 & 0.233 & 11.697 \\
$\mathrm{SD}$ & & & & & & & \\
$\begin{array}{l}\text { Control } \\
\mathrm{N}=154\end{array}$ & 4.078 & 1.696 & 1.265 & 1.043 & 1.421 & 0.233 & 16.866 \\
$\mathrm{SD}$ & & & & & & & \\
$\begin{array}{l}\mathrm{t}-\mathrm{value} \\
\mathrm{DF}(\mathrm{N}-2)\end{array}$ & 5.089 & 4.998 & 3.762 & 3.178 & 4.744 & -0.195 & 5.031 \\
$\mathrm{p}-\mathrm{value}$ & 0.000 & 0.000 & 0.000 & 0.002 & 0.000 & 0.845 & 0.000 \\
\hline
\end{tabular}

The above table indicates a significant $t$-test for equality of means $(\mathrm{t}(292)=5.031, \mathrm{p}<0.001)$ for the total pupil percentage score between the post-test experimental and post-test control groups. This implies that the differences in scores between the post-test experimental group and the post-test control group were significant. There was also a significant t-test score difference in the mean scores of all the indicated thinking skills except 'evaluation'. It should also be noted that the Standard Deviations (SD) for 'knowledge' were highest in both the experimental $(S D=2.874)$ and control $(S D=4.078)$ groups and lowest for 'analysis' in both the experimental $(\mathrm{SD}=0.534)$ and control $(\mathrm{SD}=1.043)$ groups. Having established that experimental schools performed better than control schools, it was necessary to establish the trend within the experimental schools themselves. This would further confirm the reported positive effect of using 2-D animation. Table 8 illustrates the comparison of the means of the pre-test and posttest experimental schools.

Table 8: Comparison of Mean Scores of Pre-test and Post-test Groups

\section{Experimental}

\begin{tabular}{llllllc}
\hline Mean Scores & Knowledge & $\begin{array}{c}\text { Compre- } \\
\text { hension }\end{array}$ & $\begin{array}{c}\text { Applica- } \\
\text { tion }\end{array}$ & Analysis & Synthesis & $\begin{array}{c}\text { Evalua- } \\
\text { tion }\end{array}$ \\
\hline Pre-test & 21.25 & 5.76 & 5.92 & 4.6 & 4.85 & 0.89 \\
Post-test & 22.03 & 6.12 & 6.49 & 4.79 & 5.34 & 0.94 \\
\hline
\end{tabular}

Table 8 indicates a positive gain in the mean scores of the pre-test and the post-test results of the experimental schools in all levels of thinking under study. To ascertain the level of significance of the differences of the mean scores registered in Table 8, the t-values and Standard Deviations (SD) of the pre and post-test results were compared (Table 9).

\section{Table 9: T-test Scores of Pre-test and Post-test Experimental Groups}




\begin{tabular}{lccccccc}
\hline Mean Scores & $\begin{array}{c}\text { Know- } \\
\text { ledge }\end{array}$ & $\begin{array}{c}\text { Compre- } \\
\text { hension }\end{array}$ & $\begin{array}{c}\text { Applica- } \\
\text { tion }\end{array}$ & Analysis & Synthesis & $\begin{array}{c}\text { Evalua- } \\
\text { tion }\end{array}$ & $\begin{array}{c}\text { Percentage } \\
\text { Total }\end{array}$ \\
\hline $\begin{array}{l}\text { Pre-test } \\
\mathrm{N}=149\end{array}$ & 3.236 & 1.592 & 1.464 & 0.936 & 1.317 & 0.311 & 13.577 \\
$\mathrm{SD}$ & & & & & & & \\
$\begin{array}{l}\text { Post-test } \\
\mathrm{N}=140\end{array}$ & 2.874 & 1.160 & 0.902 & 0.534 & 1.001 & 0.233 & 11.697 \\
$\mathrm{SD}$ & & & & & & & \\
$\mathrm{t}-\mathrm{value}$ & -2.162 & -2.204 & -3.980 & -2.010 & -3.496 & -1.548 & -3.171 \\
$\mathrm{DF}(\mathrm{N}-2)$ & 287 & 287 & 287 & 287 & 287 & 287 & 287 \\
$\mathrm{p}-\mathrm{value}$ & 0.031 & 0.028 & 0.000 & 0.045 & 0.001 & 0.123 & 0.002 \\
\hline
\end{tabular}

The $\mathrm{p}$-values in the above table indicate a significant $\mathrm{p}$-value for the total percentage score and for all the indicated thinking skills under study except evaluation. Table 9 also shows that within the levels of thinking, the Standard Deviations (SD) for 'knowledge' were highest in both the experimental $(\mathrm{SD}=3.236)$ and control $(S D=2.874)$ groups and lowest for 'evaluation' in both the experimental $(S D=0.311)$ and control $(\mathrm{SD}=0.233)$ groups.

The results in Table 9 are in tandem with earlier results that indicated that the post-test mean scores of experimental schools had significant p-values as compared with the pre-test scores of control schools in all thinking skills except evaluation. Both sets of results consequently reaffirm, on the basis of classification of pupil's schools, the positive effect the utilization of 2-D animation had on effective communication.

\section{Discussion and Interpretation of the Findings}

First, in identifying how good hygiene practice messages were being communicated to children in Githurai, the study sought to establish the specific hygiene concerns that directly affect children in the location. A majority of respondents (69\%) reported that the study area had hygiene concerns that could affect the children in the area (Figure 1). Some of the hygiene concerns reported included lack of clean supply of water $(25.6 \%)$, lack of clean toilets $(25.6 \%)$, and lack of good garbage disposal mechanisms (18\%).

The study then sought to establish how the identified hygiene concerns were addressed in the curriculum. It was observed that these issues are covered under various topics and that the learning outcomes also directly made reference to these topics. From the interviews with teachers, $91 \%$ of respondents reported in Figure 2 that the Standard Two Ministry of Education Primary Science Syllabus had adequate content in its hygiene topics to address the identified concerns in the study area. Further, some of the learning outcomes of the syllabus were to enable the pupils to: clean their personal items; clean the classrooms and compound and dispose refuse appropriately and to use pit-latrines and flush toilets (KIE 2002, p. 43).

On the specific strategies employed by teachers to communicate hygiene messages, to the children, the teachers as indicated in Table 2, reported that a number of methods were being used. These included plays, song and dance (65.2\%), physical discussion (19.6\%) and visual language (4.3\%). It was noted that a $10.9 \%$ of the teachers reported not using any particular method for communication. It is also worthy to note that all (100\%) of the respondents reported the non- utilization of any form of ICT (and specifically 2-D animation) as one of the instructional resources used in the teaching of hygiene in the study area. Reasons given for the non use of ICT facilities included: lack of facilities and resources $(33.3 \%)$ and that the pupils were too young to understand (10.2) \%, while $51.3 \%$ of respondents did not know why animation was never utilized for communication on hygiene (Table 3). The non-use of ICT facilities is however against the expectations of the WSSCS and WHO report (2005) that argued for considerations to be made for the utilization of ICT in the health sector as this could enhance effective communication of health messages to target populations. This gap confirms the need for an ICT related 
medium intervention, such as 2-D animation, as a viable mode to be used to communicate good hygiene practice messages to the target group.

When the experimental group was 'treated' with the developed 2-D animation, the results obtained from the pupil's tests showed that there was a significant difference in performance between the experimental and control groups as recorded in Table 6. It was evident that the experimental group posted significantly better results than the control group. This was contrary to the null hypothesis of the study that there would be no significant improvement in the acquisition of knowledge on proper hygiene by children before and after interaction with 2-D animation.' The test results proved that animation did have a positive impact on the pupil's performance in all thinking skills except evaluation.

Knowledge posted the best results in both the pre and posttests. It also registered the greatest improvement in mean score after the treatment. This implies that knowledge as a skill is most impacted by animation perhaps because it is the lowest of the thinking skills in the Taxonomy and is therefore relevant to the level of children who took the test (Anderson et al., 2001). On the other hand, the lack of significant gain in the skill of evaluation could be due to the fact that the skill is a more advanced thinking level for the level of children who took the test (Anderson et al., 2001).

\section{Conclusion}

Having classified health challenges worldwide as security threats, scholars have gone further to categorize the processes that could be applied when identifying and responding to given health threats. One of the processes is the use of effective communication in mobilizing groups that would combat identified health threats.

The results presented in this paper indicate that 2-D Animation should be considered, after further study and scrutiny, as an ICT-Mitigator for effective communication as its use gave significant results when communicating hygiene messages to children in the experimental groups than in the control groups in all the thinking levels of the Bloom's Taxonomy of Educational Objectives of the Cognitive Domain except 'evaluation.' Evaluation posted mixed results due to, among other reasons, it being a relatively a high level assessment skill for the target group.

\section{Recommendation}

Arising from the obtained results, the following recommendations that relate to methods used in communicating good hygiene practice messages on preventative health care to children and the efficacy of 2-D Animation in that communication were drawn.

- This study affirms the use of ICT- based solutions, such as 2-D animation, in programmes that offer practical solutions in health and security. It targeted children, irrespective of their gender or aptitude and recorded significant improvements in mean score gain arising from the use of the technology in all skills in the Bloom's Taxonomy of Educational Objectives of the Cognitive Domain except evaluation. Due to the positive results, programmes that could be considered for inclusion of the ICT-based solutions are the forthcoming Kenyan One- Laptop- per- Child (OLC) project, the Kenya Vision 2030 and the United Nation's Sustainable Millennium Goals (SDG's.) Champoux (2001, p. 80) confirms the adoption of ICT- based solutions in community mobilization by writing that 'animated films are a rich resource for use in organizational behavior and management courses.'

- Clear policy guidelines on the utilization of ICT-based solutions in health and security should be drawn. Before this is done however, further and extensive studies on the effect of other forms 
of ICT-based solutions on different segments of society should be carried out. More studies should also be on the effects of ICT-based solutions on behavioral change or visual literacy of the respondents. Further confirmatory studies on the effect of ICT-based solutions on 'Evaluation', should be done as they presented mixed results with the target group in this study.

The policy guidelines would then be drawn after wide consultations between the Ministries of Health, Education and Information, through Kenya Institute of Education (KIE) and the Kenya National Examinations Council (KNEC). Views of other players in the ICT, Health, Security and Community Development should also be considered.

\section{References}

Anderson, L. W. \& D. R. Krathwohl, (Eds.). (2001). A taxonomy for learning, teaching and assessing: A revision of Bloom's Taxonomy of educational objectives. New York: Longman.

Baker E., M. Barrett \& L. Roberts (2002). Working Communication, Sydney: John Wiley \& Sons Australia, Ltd.

Champoux, J. E. (2001). Animated Films as a Teaching Resourse. Journal of Management Education, Sage Publications. Retrieved 09/10/10 from htpp://jme.sagepub. com/content/25/1/79.

Fraenkel, J. R., \& N. E. Wallen (2009). How to Design and Evaluate Research in Education. (6 $\left.{ }^{\text {th }} \mathrm{ed}.\right)$ New York: Mc-Graw-Hill.

Gichuki C., G. Vikiru \& S. Nyaga (2007). Using ICT Innovations to Enhance the Development of Periurban Communities in Informal Settlements in Nairobi, Kenya. Unpublished Research Project Report, Kenyatta University.

Ginman, M. \& S. von Ungern-Sternberg (2003). Cartoons as Information. Journal of Information Science, Sage Publications. Retrieved 17/09/10 from htpp://jis.sagepub. com/content/29/1/69.

Government of Kenya (1976). National Committee on Education Objectives and Policies (Gachathi Report). Nairobi: Government Printer.

Kenya Institute of Education (2002). Primary Education Syllabus, Volume 2. Nairobi: KIE.

McAlpine M. (2002). Principles of Assessment. Luton, CAA Centre: University of Luton.

Mugenda, A. G. (2008). Social Science Research- Theory and Principles. Nairobi. Applied Research \& Training Services.

Smolinski M, M. Hamburg \& J. Lederman (eds). (2003). Microbial Threats to Health: Emergence, Detection, and Response. Washington, DC: National Academies Press, p. xvii.

Yuk-ping C. L \& N. Thomas (2010). How is health a security issue? Politics, responses and issues. London: Oxford University Press.

The Lancet (2009). Swine influenza: how much of a global threat. The Lancet 373: 1495.

World Health Organisation and Water Supply \& Sanitation Collaborative Council (2005). Sanitation and Hygiene Promotion. Geneva, Switzerland: WHO Press.

\section{About the Author}

George Vikiru is a faculty in the Department of Fine Art, Kenyatta University, Kenya. 